\title{
Silicon and Plants: Current Knowledge and Technological Perspectives
}

\author{
Marie Luyckx ${ }^{1}$, Jean-Francois Hausman ${ }^{2}$, Stanley Lutts ${ }^{1 *}$ and Gea Guerriero ${ }^{2 *}$ \\ 'Groupe de Recherche en Physiologie Végétale, Earth and Life Institute - Agronomy, Université Catholique de Louvain, \\ Louvain-la-Neuve, Belgium, ${ }^{2}$ Environmental Research and Innovation Department, Luxembourg Institute of Science and \\ Technology, Esch-sur-Alzette, Luxembourg
}

\section{OPEN ACCESS}

Edited by:

Rupesh Kailasrao Deshmukh,

Laval University, Canada

Reviewed by:

Rivka Elbaum,

Hebrew University of Jerusalem, Israel

Md Aminul Islam,

National Institute of Plant Genome

Research, India

*Correspondence:

Stanley Lutts

stanley.lutts@uclouvain.be

Gea Guerriero

gea.guerriero@list.lu

Specialty section:

This article was submitted to

Plant Nutrition,

a section of the journa

Frontiers in Plant Science

Received: 24 January 2017 Accepted: 10 March 2017

Published: 23 March 2017

Citation:

Luyckx M, Hausman J-F, Lutts S and Guerriero G (2017) Silicon and Plants:

Current Knowledge and Technological Perspectives. Front. Plant Sci. 8:411. doi: 10.3389/fpls.2017.00411
Elemental silicon (Si), after oxygen, is the second most abundant element in the earth's crust, which is mainly composed of silicates. Si is not considered essential for plant growth and development, however, increasing evidence in the literature shows that this metalloid is beneficial to plants, especially under stress conditions. Indeed Si alleviates the toxic effects caused by abiotic stresses, e.g., salt stress, drought, heavy metals, to name a few. Biogenic silica is also a deterrent against herbivores. Additionally, $\mathrm{Si}$ ameliorates the vigor of plants and improves their resistance to exogenous stresses. The protective role of Si was initially attributed to a physical barrier fortifying the cell wall (e.g., against fungal hyphae penetration), however, several studies have shown that the action of this element on plants is far more complex, as it involves a cross-talk with the cell interior and an effect on plant metabolism. In this study the beneficial role of $\mathrm{Si}$ on plants will be discussed, by reviewing the available data in the literature. Emphasis will be given to the protective role of Si during (a)biotic stresses and in this context both priming and the effects of Si on endogenous phytohormones will be discussed. A whole section will be devoted to the use of silica $\left(\mathrm{SiO}_{2}\right)$ nanoparticles, in the light of the interest that nanotechnology has for agriculture. The paper also discusses the potential technological aspects linked to the use of $\mathrm{Si}$ in agriculture and to modify/improve the physical parameters of plant fibers. The study indeed provides perspectives on the use of Si to increase the yield of fiber crops and to improve the thermal stability and tensile strength of natural fibers.

Keywords: silicic acid, biosilicification, stresses, priming, cell wall

\section{INTRODUCTION}

Silicon (Si) is considered non-essential (or quasi-essential, Epstein and Bloom, 2005) for plant growth and development. Plants develop well in its absence, although in some cases, e.g., the silicifier horsetail and rice, the absence of Si triggers increased susceptibility to fungal infection (Datnoff and Rodrigues, 2005; Law and Exley, 2011). When supplied to the growth medium (as silicic acid, vide infra), plant vigor and resistance to (a)biotic stresses increase (Azeem et al., 2015; Coskun et al., 2016; Guerriero et al., 2016a). Si is taken up by plants as silicic acid $\mathrm{Si}(\mathrm{OH})_{4}$ via aquaporin type channels (Nod26-like intrinsic proteins, NIPs) (Ma et al., 2006; Grégoire et al., 2012; Deshmukh et al., 2013). A specific 108 amino acid spacing between the conserved NPA domains 
determines $\mathrm{Si}(\mathrm{OH})_{4}$ permeability (Deshmukh et al., 2015). Plants are classified into accumulators, excluders and intermediate type (Mitani and Ma, 2005), depending on the amount of biogenic silica found in their tissues. Among the accumulators are Equisetales, Cyperales and Poales: in Graminae, rice is the highest silicifier where $\mathrm{Si}$ (in the form of biogenic silica, vide infra) accounts for up to $10 \%$ of the shoot dry weight (Ma et al., 2002). Tomato is among the excluders, while Urtica dioica (i.e., nettle) is an intermediate type (Trembath-Reichert et al., 2015).

In (some) plants the provision of $\mathrm{Si}(\mathrm{OH})_{4}$ has a latent effect in the absence of an external stimulus (Fauteux et al., 2005, 2006). This has been observed in the Arabidopsis-powdery mildew pathosystem (Fauteux et al., 2006). It should, however, be noted that in rice, $\mathrm{Si}(\mathrm{OH})_{4}$ supplementation does trigger major changes, as it induces the upregulation and downregulation of 35 and 121 transcription factors respectively (Van Bockhaven et al., 2012). This difference may be in part due to the different cell wall types (Yokoyama and Nishitani, 2004) and to the structural importance of $\mathrm{Si}$ in type II cell walls (i.e., cell walls characterized by the presence of more phenylpropanoids as compared to type I cell walls in dicots).

By precipitating as $\mathrm{SiO}_{2}$ and being incorporated into biological structures (e.g., the cell wall, vide infra), Si exerts its protective action via the formation of a physical barrier. However, this passive role is too simplistic and does not explain why plants supplemented with $\mathrm{Si}$ are better suited to face exogenous stresses. Compelling evidence in the literature shows that specific cell wall components trigger $\mathrm{SiO}_{2}$ precipitation (reviewed by Guerriero et al., 2016a). In rice cell suspension culture, a hemicellulosebound form of Si has been identified (He et al., 2015), in horsetail mixed-linkage glucans (MLGs) have been proposed to participate in $\mathrm{SiO}_{2}$ formation (Fry et al., 2008) and this has been recently confirmed in rice where overexpression of a hydrolase acting on MLGs was shown to affect silicification (Kido et al., 2015). In horsetail, callose was shown to template biosilicification (Law and Exley, 2011). Very recently, the role of callose in templating biosilicification has been additionally proven by using Arabidopsis plants either overexpressing or lacking the callose synthase gene PMR4 (Brugiére and Exley, 2017): while the wildtype plants and overexpressors responded to a pathogen-like challenge by accumulating both callose and silica, the mutants did not produce callose and, consequently, deposited significantly less silica.

\section{Si PRIMING}

Several papers demonstrated that $\mathrm{Si}(\mathrm{OH})_{4}$ (hereafter referred to as Si for simplicity) acts as a "tonic" by priming plants, i.e., by preparing the defense responses which are then fully deployed at the onset of the stress, as will be discussed in detail in the next sections. The effects of Si under normal conditions are indeed latent, since, for the majority of the studies available, no major modifications, e.g., in gene expression, are observed. Under control conditions Si probably activates the metabolic status of the plant, by making it more efficient in responding to exogenous stimuli.
In rice, a $\mathrm{Si}$-accumulator, $\mathrm{Si}$ causes alterations of $\mathrm{C} / \mathrm{N}$ balance in the source-sink relationship under unstressed conditions, by favoring a remobilization of amino acids to support the increased $\mathrm{N}$ demand during grain development (Detmann et al., 2012, 2013). These data support the hypothesis that Si has a signaling role in plant cells. Si was indeed suggested to have a role as second messenger by binding to the hydroxyl groups of proteins involved in cell signaling, thereby partaking in the signal transduction (Fauteux et al., 2005).

It is important to mention that $\mathrm{Si}$ primes defense responses also in Si non-accumulators, i.e., tomato (Ghareeb et al., 2011): tomato is protected against Ralstonia solanacearum by $\mathrm{Si}$ which causes an upregulation, upon infection, of genes involved in ethylene and jasmonic acid signaling, i.e., JERF3, TRSF1, ACCO, as well as genes involved in stress response, i.e., trehalose phosphatase, late embryogenesis abundant protein, ferritin. In this study, the authors also observed an increased expression of a negative regulator of the jasmonic acid signal, JAZ1, together with a ubiquitin protein-ligase: the authors propose that $J A Z 1$ helps in preventing the eventual damage caused by the stimulation of defense-related compounds and that the ubiquitin protein-ligase may degrade JAZ1. In tomato challenged by $R$. solanacearum, Si also upregulates a MAPK (MAPK19), a WRKY transcription factor and linker histones (H1 and H5). These findings corroborate the role of Si in intracellular signaling and suggest its involvement in transcription too (Ghareeb et al., 2011).

Silicon was shown to upregulate the expression of a leucinerich repeat receptor-like kinase (LRR-RLK) in rice (Fleck et al., 2011), which is a protein involved in intracellular signal transduction. High-throughput technologies relying on -omics will help shed light on the missing genes/proteins involved in the signal transduction underlying Si priming (the so-called "primeomics"; Balmer et al., 2015).

\section{Si AND ABIOTIC STRESS ALLEVIATION}

Si assumes key functions in the plant response to numerous environmental constraints. Two major processes contributing to stress resistance are commonly considered (i) a physical and mechanical protection afforded by $\mathrm{SiO}_{2}$ deposits and (ii) a biochemical response triggering metabolic changes. The precise distribution/speciation of accumulated Si in plant tissue allows us to gain additional information regarding its modalities of action and requires the use of biophysical tools, such as laser ablation (LA), extended X-ray fine structure (EXAFS), X-ray absorption near edge structure (XANES) and micro particle-induced X-ray emission (micro-PIXE).

According to Liang et al. (2013), Si improves lodging resistance by strengthening the stem basis in rice. It also enhances UV tolerance due to the protective effect of Si deposition bodies on the leaf epidermis (Goto et al., 2003) or by reducing UVBinduced membrane damages (Shen et al., 2010).

Silicon influences water relations in drought-treated plants: it induces the formation of a silica cuticle double layer under the leaf epidermis which reduces water losses through cuticular 
transpiration (Gong et al., 2003). Si also reduces stomatal conductance in relation to turgor loss of guard cells resulting from Si deposition and modified cell wall properties (Zhu and Gong, 2014). Si improvement of drought resistance may also be ascribed to strong abilities to extract water from the soil as a consequence of Si-related promotion of root elongation (Hattori et al., 2005) and up-regulation of aquaporin genes (Liu et al., 2015).

Silicon contributes to salt stress alleviation through inhibition of $\mathrm{Na}^{+}$(Zhu and Gong, 2014) and $\mathrm{Cl}^{-}$(Shi et al., 2013) uptake. Translocation of toxic ions from root to shoot is also reduced by Si supply (Savvas and Ntatsi, 2015). In rice, Si alleviates $\mathrm{NaCl}$ toxicity by blocking the transpirational bypass flow through precipitation as $\mathrm{SiO}_{2}$ in exodermis and endodermis (Yeo et al., 1999). Potassium uptake allowing the maintenance of $\mathrm{K} / \mathrm{Na}$ is improved by Si nutrition which has a direct stabilizing effect on proton pump activity in salt-treated root tips (Xu et al., 2015).

In metal-polluted soil, Si may influence the bioavailability of toxic elements. The presence of soil sodium metasilicate or alkaline Si-containing material may induce a rise in the rhizospheric $\mathrm{pH}$ leading to a decrease in available heavy metal concentration in the soil ( $\mathrm{Wu}$ et al., 2013). Soluble silicate hydrolyzes to generate gelatinous metasilicic acid $\left(\mathrm{H}_{2} \mathrm{SiO}_{3}\right)$ retaining heavy metals ( $\mathrm{Gu}$ et al., 2011). According to Kidd et al. (2001), Si-treated plants may also exude phenolics such as catechin and quercetin having strong Al-chelating abilities. The formation of hydroxyl-aluminum silicate in the apoplast also contributes to $\mathrm{Al}$ detoxification (Wang et al., 2004).

Compartmentation of toxic ions is an important process in heavy metal tolerance. Si improves heavy metal retention by roots, with an obvious accumulation in the endodermis (Keller et al., 2015). At the shoot level, accumulation of Mn was mainly observed in epidermis in response to Si treatment (Doncheva et al., 2009). Iwasaki and Matsumura (1999) reported that Si increases $\mathrm{Mn}$ accumulation in the leaf trichomes. Controversial data are available in the literature regarding co-precipitation of $\mathrm{Si}$ with heavy metals. Keller et al. (2015) did not detect $\mathrm{Cu}$ and $\mathrm{Cd}$ in phytoliths and the absence of $\mathrm{Cu}-\mathrm{Si}$ coprecipitation was also noticed in maize by Collin et al. (2014). He et al. (2013), however, identified a mechanisms of co-deposition of Si and Cd in the rice cell walls via a [Si-wall matrix] $\mathrm{Cd}$ complexation, which may explain a Si-induced decrease in the Cd influx in cells. Ma et al. (2015) considered that a hemicellulose bound form of $\mathrm{Si}$ with a net negative charge is responsible for inhibition of Cd uptake leading to a downregulation of Nramp5 coding for a transporter involved in Cd transport. Kim et al. (2014) also reported a downregulation of other heavy metals transporter (OsHMA2 and OsHMA3) when $\mathrm{Cu} / \mathrm{Cd}$-treated rice was supplied by $\mathrm{Si}$.

Numerous studies reported that $\mathrm{Si}$ induces an improved behavior of heavy metal-treated plants in relation to regulation of antioxidant enzymes (Adrees et al., 2015), oversynthesis of endogenous antioxidants leading to mitigation of oxidative stress (Imtiaz et al., 2016), maintenance of net photosynthesis relying on the stabilization of chloroplast structures, PSII integrity and increased pigment concentration (Nwugo and Huerta, 2008; Tripathi et al., 2015a). Si may thus be of paramount importance for triggering adapted plant response, but the precise molecular cues involved in the adaptative processes still need to be clearly identified.

\section{Si AND BIOTIC STRESS}

Si was reported to improve defense against biotic constraints occurring in the form of plant pathogens (fungi, bacteria, and viruses) or animals (vertebrates and arthropod herbivores).

Silicon deposition increases abrasiveness of plant tissues and thus reduces palatability and digestibility for herbivores (Massey and Hartley, 2009). Hartley et al. (2015) demonstrated by Scanning electron microscopy with energy dispersive X-ray spectroscopy (SEM-EDX) that phytolith morphology inside the tissues has more influence on abrasiveness than the actual Si concentration. Using the same technique, Keeping et al. (2009) demonstrated that the pattern of $\mathrm{Si}$ deposition in sugarcane is responsible for enhanced resistance to Eldana saccharina. Physical strength of the leaf resulting from Si accumulation may afford mechanical protection and thus lower the rate of infection as reported for Rhizoctonia solani (Zhang et al., 2013; Schurt et al., 2014) or Bipolaris oryzae (Ning et al., 2014).

Biochemical/molecular mechanisms are also induced or reinforced by $\mathrm{Si}$ allowing the plant to improve resistance to biotic stress and include defensive compounds such as phenolics, phytoalexins and momilactones (Remus-Borel et al., 2005), but also to activation of defensive enzymes such as peroxidase, polyphenol oxidase, lipoxygenase and phenylalanine ammonia lyase (Rahman et al., 2015). According to Cai et al. (2008), Si treatments may increase transcripts levels corresponding to those defense-related genes.

Reynolds et al. (2016) reported that $\mathrm{Si}$ also operates by attracting predators or parasitoids to plant under herbivore attack. Indeed, soluble Si contributes to increase herbivoreinduced plant volatiles to promote predator attraction by pestinfected plants. Moreover, according to James (2003) and Connick (2011), the phenology of insect's life cycle is also slowed down in Si-treated plants, making it more prone to predation.

\section{EFFECTS OF Si ON PHYTOHORMONES}

Silicon impacts on endogenous phytohormones are commonly analyzed in response to stress conditions. In rice plants exposed to heavy metals, Si reduced endogenous concentration of jamonic acid (JA) and salicylic acid (SA), while abscisic acid (ABA) first increased and then decreased after 14 days of treatment (Kim et al., 2014): the ABA has an antagonist behavior with JA/SA biosynthesis. The effect of such phytohormonal changes on the expression of genes involved in heavy metal response still needs to be elucidated in Si-treated plants. Kim et al. (2011) also reported that $\mathrm{Si}$ reduced JA concentration in response to wounding, while Lee et al. (2010) reported an increase in gibberellins concentration in Si-treated plants exposed to salinity.

Resistance to biotrophic pathogens may be associated with SA whereas JA and ethylene (ET) are generally associated with 
resistance to necrotrophic pathogens. Fauteux et al. (2006) showed that Si improved biosynthesis of SA, JA and ET in leaves exposed to Erysiphe cichoracearum. Similarly, Si-treated tomato plants exposed to $R$. solanacearum activated JA and ET signaling pathways to increase resistance (Ghareeb et al., 2011). Brunings et al. (2009) also provided evidence that genes controlling ET signaling pathway may be activated by $\mathrm{Si}$ treatment. Conversely, Si improves resistance to the fungus Cochliobolus miyabeanus by interfering with the production of fungal ET (Van Bockhaven et al., 2015). Data regarding the effect of Si on phytohormone metabolism in the absence of stress are still rare. Markovich et al. (2017), however, recently demonstrated that Si increases cytokinin biosynthesis in Sorghum and Arabidopsis and that such an increase may strongly contribute to delay senescence. Plant hormones interactions are responsible for a complex biochemical and physiological network: a deep understanding of $\mathrm{Si}$ influence on hormonal properties thus requires technical approaches allowing to quantify a wide range of hormonal compounds simultaneously, including minor conjugated forms.

\section{SILICA NANOPARTICLES}

The use of nanotechnology in agriculture is gaining importance because it contributes to develop new sustainable strategies. Nanomaterials can for example be engineered to immobilize nutrients or to release them in a controlled manner in the soil (Fraceto et al., 2016).

Some papers in the literature have studied the effects of silica nanoparticles (SNPs) on plant physiology and we will here review some of them.

Mesoporous SNPs (MSNPs, $20 \mathrm{~nm}$ in size) coupled to FITC were shown to be taken up by three important crops (lupin, wheat, maize), as well as Arabidopsis protoplasts and to be translocated to the aerial parts following the xylematic flow after entering the roots via symplastic/apoplastic routes (Sun et al., 2014). Very interestingly, this study also showed that MSNPs accumulated in the cell walls, therefore highlighting the existence of an affinity with cell wall components. The monodisperse nature of the MSNPs and their size, achieved via a fine-tuning of $\mathrm{pH}$ and surfactant concentration, were essential for the efficient uptake by plants: the entry takes place via the pores in the cell walls of the roots cells (Sun et al., 2014).

Mesoporous SNPs were shown to boost the growth, total protein content and photosynthesis of lupin and wheat seedlings and to induce no changes in the activity of antioxidant enzymes (Sun et al., 2016). Interestingly in this study, the authors observed a shift of $14 \mathrm{~cm}^{-1}$ and $10 \mathrm{~cm}^{-1}$ in the Raman peaks of chlorophyll from wheat and lupin when isolated chloroplasts were incubated with MSNPs suggesting a change in the molecular structure of chlorophyll.

Silica nanoparticles were shown to protect wheat seedlings against UV-B stress by stimulating the antioxidant defense system (Tripathi et al., 2016). In particular, SNPs reduced the adverse effects of the UV-B stress, i.e., low fresh weight, reduction in chlorophyll and tissue damage. Since the levels of nitric oxide reached a peak after UV-B+SNPs treatment, a protective role via the modulation of NO levels was proposed by the authors.

Silica nanoparticles also conferred protection via mitigation of oxidative stress in pea seedlings treated with $\mathrm{Cr}(\mathrm{VI})$ : the activities of enzymes such as superoxide dismutase, ascorbate peroxidase increased significantly in the presence of SNPs, while catalase, glutathione reductase and dehydroascorbate reductase were less inhibited by $\mathrm{Cr}(\mathrm{VI})$ in the presence of SNPs (Tripathi et al., 2015b).

Silica nanoparticles $(12 \mathrm{~nm})$ were also found to improve germination in a known Si-excluder, tomato: at a concentration of $8 \mathrm{~g} / \mathrm{L}$, SNPs improved seedling germination, as well as fresh and dry weight by 116.6 and $117.5 \%$ respectively (Siddiqui and Al-Whaibi, 2014).

Nanostructured $\mathrm{SiO}_{2}$ (TMS) was shown to be valuable in larch seedling production, because, when applied to the roots of 1 -yearold seedlings via soaking for $6 \mathrm{~h}$, it promoted lateral root growth, main root length and chlorophyll content (Bao-shan et al., 2004).

The effect of SNPs was, however, shown to be dependent on the plant species, as in Bt-transgenic cotton they significantly decreased plant growth (Le et al., 2014). SNPs toxicity may be linked to $\mathrm{pH}$ and nutrient adsorption problems. Indeed, in thale cress, SNPs phytotoxicity was triggered when the $\mathrm{pH}$ of the medium was not adjusted or silanol groups were not removed from the surface (Slomberg and Schoenfisch, 2012). The alkaline $\mathrm{pH}$ ( $\mathrm{pH} 8$ ca.) makes nutrients less available for uptake, while the negatively charged SNPs tend to adsorb nutrients.

\section{Si AND FIBER CROPS}

Fiber crops like textile hemp (Cannabis sativa L.) are natural resources which provide long and strong cellulosic fibers (a.k.a. bast fibers) used in both the textile and biocomposite sectors (Guerriero et al., 2014; Andre et al., 2016; Guerriero et al., 2016b). Given the positive effects of Si on plants, its use for fiber crop growth may provide an enhanced biomass yield and, therefore, an increased production of bast fibers. The association of $\mathrm{SiO}_{2}$ with the fiber cell walls may provide new properties, notably and increased durability. In this respect, it should be noted that hemp woody fibers, which contain $\mathrm{SiO}_{2}$ and therefore bind well with lime, are already used to manufacture a lightweight concrete-like material used in eco-construction and known as hempcrete. The few studies available on the specific Si impact on fiber crops confirm protection against abiotic stresses. In ramie [Boehmeria nivea (L.) Gaud.], the application of $\mathrm{Si}$ ameliorated $\mathrm{Cd}$ toxicity via stimulating the activities of antioxidant enzymes (Tang et al., 2015). Bakry et al. (2015) and Shedeed et al. (2016) reported that foliar application of Si improved the nutrient status of flax and increased straw and oil yield/plant.

Silicon accumulation in fiber crops is genetically controlled, as demonstrated for bamboos by Collin et al. (2012). Exogenous $\mathrm{Si}$ did not reduce $\mathrm{Cu}$ absorption by bamboos growing on contaminated solution, but reduced toxicity symptoms (Collin et al., 2013, 2014). Si also improved the growth of cotton exposed to $\mathrm{Cd}$ but, in this case, $\mathrm{Si}$ reduced $\mathrm{Cd}$ uptake and 


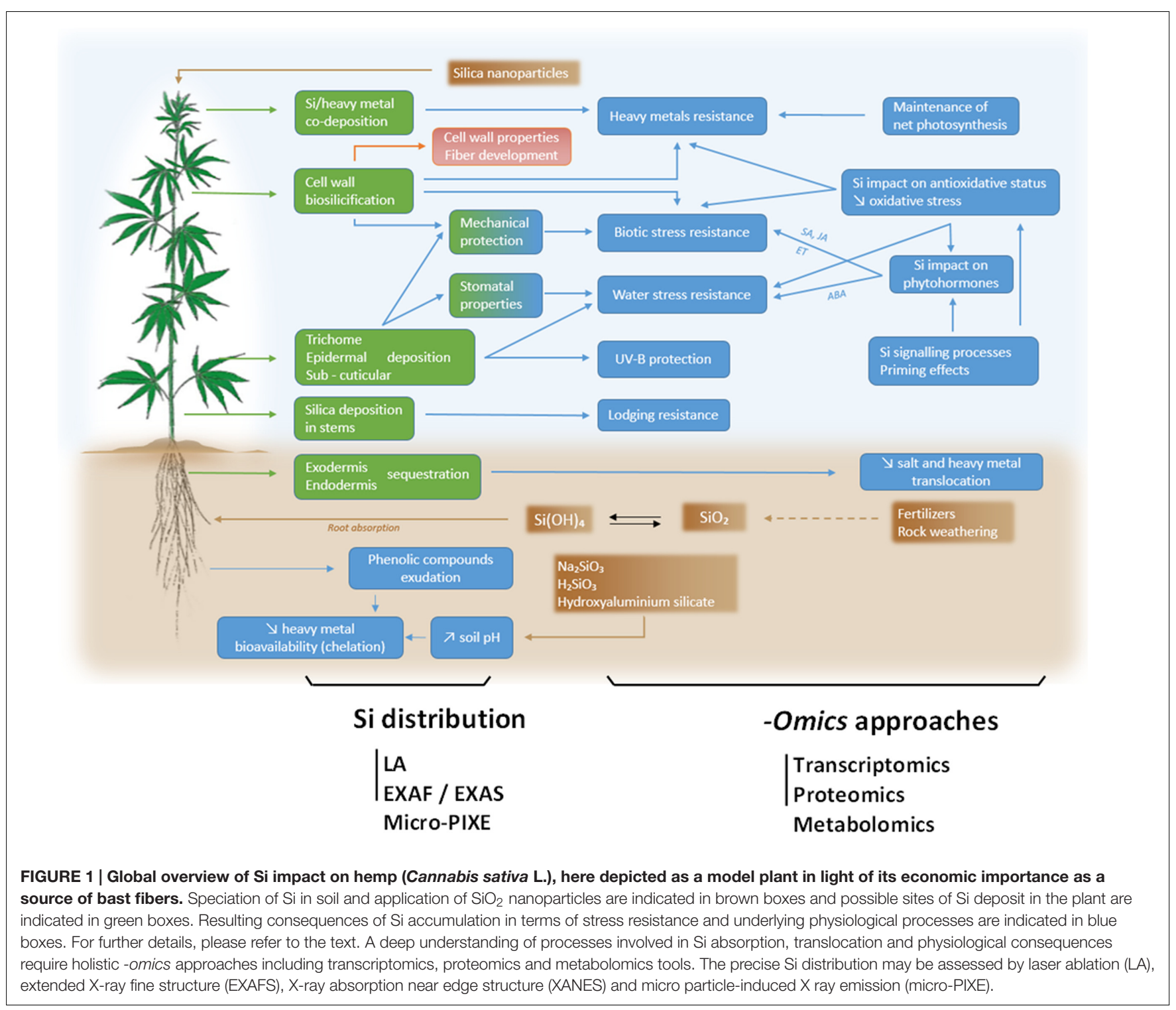

mitigated the adverse effect of this heavy metal by improving plant growth, biomass and photosynthetic parameters in stressed plants (Farooq et al., 2013).

Data concerning the direct influence of $\mathrm{Si}$ on fiber development itself are crucially lacking. Some old studies, however, provided indirect evidences that $\mathrm{Si}$ may assume important functions in this respect. Khan and Roy (1964) reported that soil application of silicate improved the size of the commercial fiber jute by increasing cell elongation and fineness. According to Boylston (1988), the Si concentration is high during the elongation phase of cotton fiber development but decreases as the fiber matures. The ratio of the amount of Si per mass of fiber peaks at the time when secondary wall initiation occurs (Boylston et al., 1990). Si is known to interact with cell walls (see Introduction), although the mechanisms underlying the final incorporation of polymerized Si into the cell wall remain elusive. Kido et al. (2015) recently demonstrated that the interaction of mixed linkage glucan $(1 ; 3,1 ; 4)-\beta$-D-glucan with Si may have obvious mechanical consequences.

Si beneficial influence on natural fiber properties is confirmed by the use of Si-containing compounds during industrial processing of harvested fibers. Natural fibers are gaining attention in engineering composite industry. However, cell wall polymers often bear hydrophilic hydroxyl groups able to form new hydrogen bonds with water molecules, which hinder hydroxyl group to react with the polar matrix of the composites (Mwaikambo and Ansell, 2002). Silane is an inorganic compound $\left(\mathrm{SiH}_{4}\right)$ commonly used to improve tensile strength and thermal stability of natural fibers (Abdelmouleh et al., 2004) which may be due to the emergence of Si-O-C and $\mathrm{Si}-\mathrm{O}-\mathrm{Si}$ links on the cellulose surface (Lu et al., 2013). Other Si treatment, including siloxane and nano Si dioxide are also used for similar purposes (Kabir et al., 2012; Siengchin and Dangtungee, 2014; Orue et al., 2016). It may thus be hypothesized that Si treatment in vivo during 
fiber development (and not only in vitro on harvested mature fibers) may lead to several promising application. This exciting goal, however, requires a multidisciplinary approach to gain a better understanding of Si influence on the modalities of fiber development (Figure 1).

\section{CONCLUSION AND FUTURE PERSPECTIVES}

Silicon is an abundant element on Earth and its positive effects on plants make it important in agriculture. The study of the Siplant binomium has still much to teach us and this is particularly the case for e.g., the cell wall-related mechanisms underlying its prophylactic role under stress. The plant cell wall takes active part in the response to (a)biotic stresses by establishing a signaling cascade toward the cell interior (Hamann, 2015) and by undergoing a remodeling (Tenhaken, 2014). It is therefore

\section{REFERENCES}

Abdelmouleh, M., Boufi, S., Belgacem, M. N., Duarte, A. P., Salah, A. B., and Gandini, A. (2004). Modification of cellulosic fibres with functionalised silanes: development of surface properties. Int. J. Adhes. Adhes. 24, 43-54. doi: 10.1016/ S0143-7496(03)00099-X

Adrees, M., Ali, S., Rizwan, M., Zia-Ur-Rehman, M., Ibrahim, M., Abbas, F., et al. (2015). Mechanisms of silicon-mediated alleviation of heavy metal toxicity in plants: a review. Ecotoxicol. Environ. Saf. 119, 186-197. doi: 10.1016/j.ecoenv. 2015.05.011

Andre, C. M., Hausman, J.-F., and Guerriero, G. (2016). Cannabis sativa: the plant of the thousand and one molecules. Front. Plant Sci. 7:19. doi: 10.3389/fpls.2016. 00019

Azeem, M., Iqbal, N., Kausar, S., Javed, M. T., Akram, M. S., and Sajid, M. A. (2015). Efficacy of silicon priming and fertigation to modulate seedling's vigor and ion homeostasis of wheat (Triticum aestivum L.) under saline environment. Environ. Sci. Pollut. Res. 22, 14367-14371. doi: 10.1007/s11356-0154983-8

Bakry, B. A., Shedeed, S. I., and Nofal, O. A. (2015). Production and quality traits of two flax varieties as affected by foliar application of silicon fertilizers under sandy soil conditions. Res. J. Pharm. Biol. Chem. Sci. 6, 181-188.

Balmer, A., Pastor, V., Gamir, J., Flors, V., and Mauch-Mani, B. (2015). The 'primeome': towards a holistic approach to priming. Trends Plant Sci. 20, 443-452. doi: 10.1016/j.tplants.2015.04.002

Bao-shan, L., shao-qi, D., Chun-hui, L., Li-jun, F., Shu-chun, Q., and Min, Y. (2004). Effect of TMS (nanostructured silicon dioxide) on growth of Changbai larch seedlings. J. Forest. Res. 15, 138. doi: 10.1007/BF02856749

Boylston, E. K. (1988). Presence of silicon in developing cotton fibers. J. Plant Nutr. 11, 1739-1747. doi: 10.1080/01904168809363929

Boylston, E. K., Hebert, J. J., Hensarling, T. P., Bradow, J. M., and Thibodeaux, D. P. (1990). Role of silicon in developing cotton fibers. J. Plant Nutr. 13, 131-148. doi: 10.1080/01904169009364063

Brugiére, T., and Exley, C. (2017). Callose-associated silica deposition in Arabidopsis. J. Trace Elem. Med. Biol. 39, 86-90. doi: 10.1016/j.jtemb.2016. 08.005

Brunings, A. M., Datnoff, L. E., Ma, J. F., Mitani, N., Nagamura, Y., Rathinasabapathi, B., et al. (2009). Differential gene expression of rice in response to silicon and rice blast fungus Magnaporthe oryzae. Ann. Appl. Biol. 155, 161-170. doi: 10.1111/j.1744-7348.2009.00347.x

Cai, K., Gao, D., Luo, S., Zeng, R., Yang, J., and Zhu, X. (2008). Physiological and cytological mechanisms of silicon-induced resistance in rice against blast disease. Physiol. Plant. 134, 324-333. doi: 10.1111/j.1399-3054.2008.01140.x

Collin, B., Doelsch, E., Keller, C., Cazevieille, P., Tella, M., Chaurand, P., et al. (2014). Evidence of sulfur-bound reduced copper in bamboo exposed to high clear that part of the beneficial effects of $\mathrm{Si}$ on plants is linked to direct/indirect effects on the cell wall.

In the future, research activities centered on specific aspects of the interaction Si-plants will be important to devise agricultural strategies aimed at improving crop yield.

\section{AUTHOR CONTRIBUTIONS}

GG conceived the idea of writing the paper. ML, J-FH, SL, and GG collected the literature data and wrote the manuscript.

\section{ACKNOWLEDGMENTS}

The authors gratefully acknowledge the support by the Fonds National de la Recherche, Luxembourg, (Project CANCAN C13/SR/5774202).

silicon and copper concentrations. Environ. Pollut. 187, 22-30. doi: 10.1016/j. envpol.2013.12.024

Collin, B., Doelsch, E., Keller, C., Panfili, F., and Meunier, J. D. (2012). Distribution and variability of silicon, copper and zinc in different bamboo species. Plant Soil 351, 377-387. doi: 10.1007/s11104-011-0974-9

Collin, B., Doelsch, E., Keller, C., Panfili, F., and Meunier, J. D. (2013). Effects of silicon and copper on bamboo grown hydroponically. Environ. Sci. Pollut. Res. 20, 6482-6495. doi: 10.1007/s11356-013-1703-0

Connick, V. J. (2011). The Impact of Silicon Fertilisation on the Chemical Ecology of Grapevine, Vitris vinifera Constitutive and Induced Chemical Defenses Againtst Atrhropod Pest and Their Natutral Enemies. Ph.D. thesis, Charles Sturt University, Albury-Wodonga.

Coskun, D., Britto, D. T., Huynh, W. Q., and Kronzucker, H. J. (2016). The role of silicon in higher plants under salinity and drought stress. Front. Plant Sci. 7:1072. doi: $10.3389 /$ fpls.2016.01072

Datnoff, L. E., and Rodrigues, F. A. (2005). The Role of Silicon in Suppressing Rice Diseases. APSnet. Available at: http://www.apsnet.org/publications/ apsnetfeatures/Pages/SiliconInRiceDiseases.aspx

Deshmukh, R. K., Vivancos, J., Guérin, V., Sonah, H., Labbé, C., Belzile, F., et al. (2013). Identification and functional characterization of silicon transporters in soybean using comparative genomics of major intrinsic proteins in Arabidopsis and rice. Plant Mol. Biol. 83, 303-315. doi: 10.1007/s11103-013-0087-3

Deshmukh, R. K., Vivancos, J., Ramakrishnan, G., Guérin, V., Carpentier, G., Sonah, H., et al. (2015). A precise spacing between the NPA domains of aquaporins is essential for silicon permeability in plants. Plant J. 83, 489-500. doi: 10.1111/tpj.12904

Detmann, K. C., Araújo, W. L., Martins, S. C., Fernie, A. R., and Damatta, F. M. (2013). Metabolic alterations triggered by silicon nutrition: is there a signaling role for silicon? Plant Signal. Behav. 8:e22523. doi: 10.4161/psb.22523

Detmann, K. C., Araújo, W. L., Martins, S. C., Sanglard, L. M., Reis, J. V., Detmann, E., et al. (2012). Silicon nutrition increases grain yield, which, in turn, exerts a feed-forward stimulation of photosynthetic rates via enhanced mesophyll conductance and alters primary metabolism in rice. New Phytol. 196, 752-762. doi: 10.1111/j.1469-8137.2012.04299.x

Doncheva, S. N., Poschenrieder, C., Stoyanova, Z., Georgieva, K., Velichkova, M., and Barceló, J. (2009). Silicon amelioration of manganese toxicity in Mnsensitive and Mn-tolerant maize varieties. Environ. Exp. Bot. 65, 189-197. doi: 10.1016/j.envexpbot.2008.11.006

Epstein, E., and Bloom, A. J. (2005). Mineral Nutrition of Plants: Principles and Perspectives, 2nd Edn. Sunderland: Sinauer Associates Inc.

Farooq, M. A., Ali, S., Hameed, A., Ishaque, W., Mahmood, K., and Iqbal, Z. (2013). Alleviation of cadmium toxicity by silicon is related to elevated photosynthesis, antioxidant enzymes; suppressed cadmium uptake and oxidative stress in cotton. Ecotoxicol. Environ. Saf. 96, 242-249. doi: 10.1016/j.ecoenv.2013.07.006 
Fauteux, F., Chain, F., Belzile, F., Menzies, J. G., and Bélanger, R. R. (2006). The protective role of silicon in the Arabidopsis-powdery mildew pathosystem. Proc. Natl. Acad. Sci. U.S.A. 103, 17554-17559. doi: 10.1073/pnas.0606330103

Fauteux, F., Remus-Borel, W., Menzies, J. G., and Belanger, R. R. (2005). Silicon and plant disease resistance against pathogenic fungi. FEMS Microbiol. Lett. $249,1-6$.

Fleck, A. T., Nye, T., Repenning, C., Stahl, F., Zahn, M., and Schenk, M. K. (2011). Silicon enhances suberization and lignifications in roots of rice (Oryza sativa). J. Exp. Bot. 62, 2001-2011. doi: 10.1093/jxb/erq392

Fraceto, L. F., Grillo, R., de Medeiros, G. A., Scognamiglio, V., Rea, G., and Bartolucci, C. (2016). Nanotechnology in agriculture: which innovation potential does it have? Front. Environ. Sci. 4:20. doi: 10.3389/fenvs.2016.00020

Fry, S. C., Nesselrode, B. H. W. A., Miller, J. G., and Mewburn, B. R. (2008). Mixed linkage $(1 \rightarrow 3,1 \rightarrow 4)$ - $\beta$-glucan is a major hemicellulose of Equisetum (horsetail) cell walls. New Phytol. 179, 104-115. doi: 10.1111/j.1469-8137.2008.02435.x

Ghareeb, H., Bozsó, Z., Ott, P. G., Repenning, C., Stahl, F., and Wydra, K. (2011). Transcriptome of silicon-induced resistance against Ralstonia solanacearum in the silicon non-accumulator tomato implicates priming effect. Physiol. Mol. Plant. Pathol. 75, 83-89. doi: 10.1016/j.pmpp.2010.11.004

Gong, H. J., Chen, K. M., Chen, G. C., Wang, S. M., and Zhang, C. L. (2003). Effects of silicon on growth of wheat under drought. J. Plant Nutr. 26, 1055-1063. doi: 10.1081/PLN-120020075

Goto, M., Ehara, H., Karita, S., Takabe, K., Ogawa, N., Yamada, Y., et al. (2003). Protective effect of silicon on phenolic biosynthesis and ultraviolet spectral stress in rice crop. Plant Sci. 164, 349-356. doi: 10.1016/S0168-9452(02)00419-3

Grégoire, C., Rémus-Borel, W., Vivancos, J., Labbé, C., Belzile, F., and Bélanger, R. R. (2012). Discovery of a multigene family of aquaporin silicon transporters in the primitive plant Equisetum arvense. Plant J. 72, 320-330. doi: 10.1111/j. 1365-313X.2012.05082.x

Gu, H. H., Qiu, H., Tian, T., Zhan, S. S., Deng, T. H. B., Chaney, R. L., et al. (2011). Mitigation effects of silicon rich amendments on heavy metal accumulation in rice (Oryza sativa L.) planted on multi-metal contaminated acidic soil. Chemosphere 83, 1234-1240. doi: 10.1016/j.chemosphere.2011.03.014

Guerriero, G., Hausman, J. F., and Legay, S. (2016a). Silicon and the plant extracellular matrix. Front. Plant Sci. 7:463. doi: 10.3389/fpls.2016.00463

Guerriero, G., Hausman, J. F., Strauss, J., Ertan, H., and Siddiqui, K. S. (2016b). Lignocellulosic biomass: biosynthesis, degradation and industrial utilization. Eng. Life Sci. 16, 1-16. doi: 10.1002/elsc.201400196

Guerriero, G., Sergeant, K., and Hausman, J. F. (2014). Wood biosynthesis and typologies: a molecular rhapsody. Tree Physiol. 34, 839-855. doi: 10.1093/ treephys/tpu031

Hamann, T. (2015). The plant cell wall integrity maintenance mechanismconcepts for organization and mode of action. Plant Cell Physiol. 56, 215-223. doi: $10.1093 / \mathrm{pcp} / \mathrm{pcu} 164$

Hartley, S. E., Fitt, R. N., McLarnon, E. L., and Wade, R. N. (2015). Defending the leaf surface: intra-and inter-specific differences in silicon deposition in grasses in response to damage and silicon supply. Front. Plant Sci. 6:35. doi: 10.3389/fpls.2015.00035

Hattori, T., Inanaga, S., Araki, H., An, P., Morita, S., Luxová, M., et al. (2005). Application of silicon enhanced drought tolerance in Sorghum bicolor. Physiol. Plant. 123, 459-466. doi: 10.1111/j.1399-3054.2005.00481.x

He, C., Ma, J., and Wang, L. (2015). A hemicellulose-bound form of silicon with potential to improve the mechanical properties and regeneration of the cell wall of rice. New Phytol. 206, 1051-1062. doi: 10.1111/nph.13282

He, C., Wang, L., Liu, J., Liu, X., Li, X., Ma, J., et al. (2013). Evidence for 'silicon'within the cell walls of suspension-cultured rice cells. New Phytol. 200, 700-709. doi: 10.1111/nph.12401

Imtiaz, M., Rizwan, M. S., Mushtaq, M. A., Ashraf, M., Shahzad, S. M., Yousaf, B., et al. (2016). Silicon occurrence, uptake, transport and mechanisms of heavy metals, minerals and salinity enhanced tolerance in plants with future prospects: a review. J. Environ. Manage. 183, 521-529. doi: 10.1016/j.jenvman.2016. 09.009

Iwasaki, K., and Matsumura, A. (1999). Effect of silicon on alleviation of manganese toxicity in pumpkin (Cucurbita moschata Duch cv. Shintosa). Soil Sci. Plant Nutr. 45, 909-920. doi: 10.1080/00380768.1999.10414340

James, D. G. (2003). Field evaluation of herbivore-induced plant volatiles as attractants for beneficial insects: methyl salicylate and the green lacewing, Chrysopa nigricornis. J. Chem. Ecol. 29, 1601-1609.
Kabir, M. M., Wang, H., Lau, K. T., Cardona, F., and Aravinthan, T. (2012). Mechanical properties of chemically-treated hemp fibre reinforced sandwich composites. Compos. Part B 43, 159-169. doi: 10.1016/j.compositesb.2011. 06.003

Keeping, M. G., Kvedaras, O. L., and Bruton, A. G. (2009). Epidermal silicon in sugarcane: cultivar differences and role in resistance to sugarcane borer Eldana saccharina. Environ. Exp. Bot. 66, 54-60. doi: 10.1016/j.envexpbot.2008.12.012

Keller, C., Rizwan, M., Davidian, J. C., Pokrovsky, O. S., Bovet, N., Chaurand, P., et al. (2015). Effect of silicon on wheat seedlings (Triticum turgidum L.) grown in hydroponics and exposed to 0 to $30 \mu \mathrm{M}$ Cu. Planta $241,847-860$. doi: 10.1007/s00425-014-2220-1

Khan, D. H., and Roy, A. C. (1964). Growth, p-uptake, and fibre cell dimensions of jute plant as affected by silicate treatment. Plant Soil 20, 331-336. doi: 10.1007/ BF01373823

Kidd, P. S., Llugany, M., Poschenrieder, C. H., Gunse, B., and Barcelo, J. (2001). The role of root exudates in aluminium resistance and silicon-induced amelioration of aluminium toxicity in three varieties of maize (Zea mays L.). J. Exp. Bot. 52, 1339-1352. doi: 10.1093/jexbot/52.359.1339

Kido, N., Yokoyama, R., Yamamoto, T., Furukawa, J., Iwai, H., Satoh, S., et al. (2015). The matrix polysaccharide $(1 ; 3,1 ; 4)-\beta$-D-glucan is involved in silicondependent strengthening of rice cell wall. Plant Cell Physiol. 56, 268-276. doi: $10.1093 / \mathrm{pcp} / \mathrm{pcu} 162$

Kim, Y. H., Khan, A. L., Hamayun, M., Kang, S. M., Beom, Y. J., and Lee, I. J. (2011). Influence of short-term silicon application on endogenous physiohormonal levels of Oryza sativa L. under wounding stress. Biol. Trace Elem. Res. 144, 1175-1185. doi: 10.1007/s12011-011-9047-4

Kim, Y. H., Khan, A. L., Kim, D. H., Lee, S. Y., Kim, K. M., Waqas, M., et al. (2014). Silicon mitigates heavy metal stress by regulating P-type heavy metal ATPases, Oryza sativa low silicon genes, and endogenous phytohormones. BMC Plant Biol. 14:1. doi: 10.1186/1471-2229-14-13

Law, C., and Exley, C. (2011). New insight into silica deposition in horsetail (Equisetum arvense). BMC Plant Biol. 11:112. doi: 10.1186/1471-2229-11-112

Le, V. N., Rui, Y., Gui, X., Li, X., Liu, S., and Han, Y. (2014). Uptake, transport, distribution and bio-effects of $\mathrm{SiO} 2$ nanoparticles in Bt-transgenic cotton. J. Nanobiotechnol. 5, 12-50. doi: 10.1186/s12951-014-0050-8

Lee, S. K., Sohn, E. Y., Hamayun, M., Yoon, J. Y., and Lee, I. J. (2010). Effect of silicon on growth and salinity stress of soybean plant grown under hydroponic system. Agrofor. Syst. 80, 333-340. doi: 10.1007/s10457-010-9299-6

Liang, S. J., Li, Z. Q., Li, X. J., Xie, H. G., Zhu, R. S., Lin, J. X., et al. (2013). Effects of stem structural characters and silicon content on lodging resistance in rice (Oryza sativa L.). Res. Crops 14, 621-636.

Liu, P., Yin, L., Wang, S., Zhang, M., Deng, X., Zhang, S., et al. (2015). Enhanced root hydraulic conductance by aquaporin regulation accounts for silicon alleviated salt-induced osmotic stress in Sorghum bicolor L. Environ. Exp. Bot. 111, 42-51. doi: 10.1016/j.envexpbot.2014.10.006

Lu, T., Jiang, M., Jiang, Z., Hui, D., Wang, Z., and Zhou, Z. (2013). Effect of surface modification of bamboo cellulose fibers on mechanical properties of cellulose/epoxy composites. Compos. Part B 51, 28-34. doi: 10.1016/j. compositesb.2013.02.031

Ma, J., Cai, H., He, C., Zhang, W., and Wang, L. (2015). A hemicellulose-bound form of silicon inhibits cadmium ion uptake in rice (Oryza sativa) cells. New Phytol. 206, 1063-1074. doi: 10.1111/nph.13276

Ma, J. F., Tamai, K., Ichii, M., and Wu, G. F. (2002). A rice mutant defective in si uptake. Plant Physiol. 130, 2111-2117. doi: 10.1104/pp.010348

Ma, J. F., Tamai, K., Yamaji, N., Mitani, N., Konishi, S., Katsuhara, M., et al. (2006). A silicon transporter in rice. Nature 440, 688-691. doi: 10.1038/nature04590

Markovich, O., Steiner, E., Kouøil, S., Tarkowski, P., Aharoni, A., and Elbaum, R. (2017). Silicon promotes cytokinin biosynthesis and delays senescence in Arabidopsis and Sorghum. Plant Cell Environ. doi: 10.1111/pce.12913 [Epub ahead of print].

Massey, F. P., and Hartley, S. E. (2009). Physical defences wear you down: progressive and irreversible impacts of silica on insect herbivores. J. Anim. Ecol. 78, 281-291. doi: 10.1111/j.1365-2656.2008.01472.x

Mitani, N., and Ma, J. F. (2005). Uptake system of silicon in different plant species. J. Exp. Bot. 56, 1255-1261. doi: 10.1093/jxb/eri121

Mwaikambo, L. Y., and Ansell, M. P. (2002). Chemical modification of hemp, sisal, jute, and kapok fibers by alkalization. J. Appl. Polym. Sci. 84, 2222-2234. doi: 10.1002/app.10460 
Ning, D., Song, A., Fan, F., Li, Z., and Liang, Y. (2014). Effects of slag-based silicon fertilizer on rice growth and brown-spot resistance. PLoS ONE 9:e102681. doi: 10.1371 /journal.pone.0102681

Nwugo, C. C., and Huerta, A. J. (2008). Silicon-induced cadmium resistance in rice (Oryza sativa). J. Plant Nutr. Soil Sci. 171, 841-848. doi: 10.1002/jpln.200800082

Orue, A., Jauregi, A., Unsuain, U., Labidi, J., Eceiza, A., and Arbelaiz, A. (2016). The effect of alkaline and silane treatments on mechanical properties and breakage of sisal fibers and poly (lactic acid)/sisal fiber composites. Compos. Part A 84, 186-195. doi: 10.1016/j.compositesa.2016.01.021

Rahman, A., Wallis, C. M., and Uddin, W. (2015). Silicon-induced systemic defense responses in perennial ryegrass against infection by Magnaporthe oryzae. Phytopathology 105, 748-757. doi: 10.1094/PHYTO-12-14-0378-R

Remus-Borel, W., Menzies, J. G., and Bélanger, R. R. (2005). Silicon induces antifungal compounds in powdery mildew-infected wheat. Physiol. Mol. Plant Pathol. 66, 108-115. doi: 10.1016/j.pmpp.2005.05.006

Reynolds, O. L., Padula, M. P., Zeng, R., and Gurr, G. M. (2016). Silicon: potential to promote direct and indirect effects on plant defence against arthropod pests in agriculture. Front. Plant Sci. 7:744. doi: 10.3389/fpls.2016.00744

Savvas, D., and Ntatsi, G. (2015). Biostimulant activity of silicon in horticulture. Sci. Hortic. 196, 66-81. doi: 10.1016/j.scienta.2015.09.010

Schurt, D. A., Cruz, M. F. A., Nascimento, K. J. T., Filippi, M. C. C., and Rodrigues, F. A. (2014). Silicon potentiates the activities of defense enzymes in the leaf sheaths of rice plants infected by Rhizoctonia solani. Trop. Plant Pathol. 39, 457-463. doi: 10.1590/S1982-56762014000600007

Shedeed, S. I., Bakry, B. A., and Nofal, O. A. (2016). Response of Flax (Linum usitatissimun L.) nutrients content to foliar application by two different sources of silicon fertilizers. Res. J. Pharm. Biol. Chem. Sci. 7, 373-398.

Shen, X., Zhou, Y., Duan, L., Li, Z., Eneji, A. E., and Li, J. (2010). Silicon effects on photosynthesis and antioxidant parameters of soybean seedlings under drought and ultraviolet-B radiation. J. Plant Physiol. 167, 1248-1252. doi: 10.1016/j. jplph.2010.04.011

Shi, Y., Wang, Y., Flowers, T. J., and Gong, H. (2013). Silicon decreases chloride transport in rice (Oryza sativa L.) in saline conditions. J. Plant Physiol. 170, 847-853. doi: 10.1016/j.jplph.2013.01.018

Siddiqui, M. H., and Al-Whaibi, M. H. (2014). Role of nano-SiO2 in germination of tomato (Lycopersicum esculentum seeds Mill.). Saudi J. Biol. Sci. 21, 13-17. doi: $10.1016 /$ j.sjbs.2013.04.005

Siengchin, S., and Dangtungee, R. (2014). Polyethylene and polypropylene hybrid composites based on nano silicon dioxide and different flax structures. J. Thermoplast. Compos. Mater. 27, 1428-1447. doi: 10.1177/08927057145 26916

Slomberg, D. L., and Schoenfisch, M. H. (2012). Silica nanoparticle phytotoxicity to Arabidopsis thaliana. Environ. Sci. Technol. 46, 10247-10254. doi: 10.1021/ es300949f

Sun, D., Hussain, H. I., Yi, Z., Rookes, J. E., Kong, L., and Cahill, D. M. (2016). Mesoporous silica nanoparticles enhance seedling growth and photosynthesis in wheat and lupin. Chemosphere 152, 81-91. doi: 10.1016/j.chemosphere.2016. 02.096

Sun, D., Hussain, H. I., Yi, Z., Siegele, R., Cresswell, T., Kong, L., et al. (2014). Uptake and cellular distribution, in four plant species, of fluorescently labeled mesoporous silica nanoparticles. Plant Cell Rep. 33, 1389-1402. doi: 10.1007/ s00299-014-1624-5

Tang, H., Liu, Y., Gong, X., Zeng, G., Zheng, B., Wang, D., et al. (2015). Effects of selenium and silicon on enhancing antioxidative capacity in ramie (Boehmeria nivea (L.) Gaud.) under cadmium stress. Environ. Sci. Pollut. Res. 22, 9999-10008. doi: 10.1007/s11356-015-4187-2

Tenhaken, R. (2014). Cell wall remodeling under abiotic stress. Front. Plant Sci. 5:771. doi: 10.3389/fpls.2014.00771
Trembath-Reichert, E., Wilson, J. P., McGlynn, S. E., and Fischer, W. W. (2015). Four hundred million years of silica biomineralization in land plants. Proc. Natl. Acad. Sci. U.S.A. 112, 5449-5454. doi: 10.1073/pnas.1500289112

Tripathi, D. K., Singh, S., Singh, V. P., Prasad, S. M., Dubey, N. K., and Chauhan, D. K. (2016). Silicon nanoparticles more effectively alleviated UV-B stress than silicon in wheat (Triticum aestivum) seedlings. Plant Physiol. Biochem. 110, 70-80. doi: 10.1016/j.plaphy.2016.06.026

Tripathi, D. K., Singh, V. P., Prasad, S. M., Chauhan, D. K., Dubey, N. K., and Rai, A. K. (2015a). Silicon-mediated alleviation of Cr (VI) toxicity in wheat seedlings as evidenced by chlorophyll florescence, laser induced breakdown spectroscopy and anatomical changes. Ecotoxicol. Environ. Saf. 113, 133-144. doi: 10.1016/j.ecoenv.2014.09.029

Tripathi, D. K., Singh, V. P., Prasad, S. M., Chauhan, D. K., and Dubey, N. K. (2015b). Silicon nanoparticles (SiNp) alleviate chromium (VI) phytotoxicity in Pisum sativum (L.) seedlings. Plant Physiol. Biochem. 96, 189-198. doi: 10.1016/ j.plaphy.2015.07.026

Van Bockhaven, J., De Vleesschauwer, D., and Höfte, M. (2012). “Silicon-mediated priming results in broad spectrum resistance in rice (Oryza sativa L.)," in Proceedings of the Abstract Retrieved from Abstracts of the 64th International Symposium on Crop Protection, Ghent, 62.

Van Bockhaven, J., Spíchal, L., Novák, O., Strnad, M., Asano, T., Kikuchi, S., et al. (2015). Silicon induces resistance to the brown spot fungus Cochliobolus miyabeanus by preventing the pathogen from hijacking the rice ethylene pathway. New Phytol. 206, 761-773. doi: 10.1111/nph.13270

Wang, Y., Stass, A., and Horst, W. J. (2004). Apoplastic binding of aluminum is involved in silicon-induced amelioration of aluminum toxicity in maize. Plant Physiol. 136, 3762-3770. doi: 10.1104/pp.104.045005

Wu, J. W., Shi, Y., Zhu, Y. X., Wang, Y. C., and Gong, H. J. (2013). Mechanisms of enhanced heavy metal tolerance in plants by silicon: a review. Pedosphere 23, 815-825. doi: 10.1016/S1002-0160(13)60073-9

Xu, C. X., Ma, Y. P., and Liu, Y. L. (2015). Effects of silicon (Si) on growth, quality and ionic homeostasis of aloe under salt stress. S. Afr. J. Bot. 98, 26-36. doi: 10.1016/j.sajb.2015.01.008

Yeo, A. R., Flowers, S. A., Rao, G., Welfare, K., Senanayake, N., and Flowers, T. J. (1999). Silicon reduces sodium uptake in rice (Oryza satival L.) in saline conditions and this is accounted for by a reduction in the transpirational bypass flow. Plant Cell Environ. 22, 559-565. doi: 10.1046/j.1365-3040.1999.00418.x

Yokoyama, R., and Nishitani, K. (2004). Genomic basis for cell-wall diversity in plants. A comparative approach to gene families in rice and Arabidopsis. Plant Cell Physiol. 45, 1111-1121.

Zhang, C., Wang, L., Zhang, W., and Zhang, F. (2013). Do lignification and silicification of the cell wall precede silicon deposition in the silica cell of the rice (Oryza sativa L.) leaf epidermis?. Plant Soil 372, 137-149. doi: 10.1007/s11104013-1723-Z

Zhu, Y., and Gong, H. (2014). Beneficial effects of silicon on salt and drought tolerance in plants. Agron. Sustain. Dev. 34, 455-472. doi: 10.1007/s13593-0130194-1

Conflict of Interest Statement: The authors declare that the research was conducted in the absence of any commercial or financial relationships that could be construed as a potential conflict of interest.

Copyright (c) 2017 Luyckx, Hausman, Lutts and Guerriero. This is an open-access article distributed under the terms of the Creative Commons Attribution License (CC BY). The use, distribution or reproduction in other forums is permitted, provided the original author(s) or licensor are credited and that the original publication in this journal is cited, in accordance with accepted academic practice. No use, distribution or reproduction is permitted which does not comply with these terms. 